\title{
Journal of Education
}

\section{ISSN Online: 2616-8383}

Influence of Socio-economic Factors on Academic Performance in Public Primary Schools in Murang'a South Sub County, Kenya

Njoroge Robert Njuguna

ISSN: 2616-8383 


\title{
Influence of Socio-economic Factors on Academic Performance in Public Primary Schools in Murang'a South Sub County, Kenya
}

\author{
Njoroge Robert Njuguna \\ Department of Educational Management, \\ Policy and Curriculum Studies \\ Kenyatta University \\ Corresponding author's email address: nnrobert@yahoo.com
}

\begin{abstract}
How to cite this article: Njuguna, N. R. (2021). Influence of Socio-economic Factors on Academic Performance in Public Primary Schools in Murang'a South Sub County, Kenya. Journal of Education, 4(6), 16-27. https://doi.org/10.53819/81018102t3014
\end{abstract}

\section{Abstract}

Socio-economic factors have been cited as a determinant of students' performance in national examinations. The purpose of the study was to establish the socio-economic factors which influence academic performance in public primary schools in Murang'a South Sub County. The study adopted a descriptive survey design utilizing both quantitative and qualitative techniques. The study population entailed all the public primary schools in Murang'a South Sub County, Kenya their deputy head teachers, teachers and pupils. Due to their disproportionateness, schools were stratified according to education zones and then simple randomly sampled using the lottery technique. The study involved a sample of 21 deputy head teachers, 105 teachers and 210 pupils making a total of 336 participants. Data were collected using a pupils' questionnaire, focus group discussions for the deputy head teachers and teachers, and an observation checklist. Data were analyzed using descriptive statistics: quantitative data were analyzed using Statistical Package for Social Sciences version 17 for windows. The socio-economic factors that influence academic performance included low parental/guardian education level; low income and pre-occupation with work. A large number of pupils could not carry out private studies at home. Due to poor economic status (low earnings) some families live in overcrowded and/or poorly lit rooms. Moreover, they could not afford to buy essential furniture, essential textbooks that were not issued at school, engage their children in extra coaching after school, buy internet enabled mobile phones and computers from which important information for education purposes can be assessed. Majority of the parents were found to be preoccupied with work. Their preoccupation denied them time to attend to school meetings/functions and observe behavior changes in their children. There is need for collaboration between the Government of the Republic of Kenya and development partners to work out, introduce and implement sustainable economic activities so as to alleviate poverty in the region.

Keywords: socio-economic factors, academic performance, public primary schools, Murang'a South Sub County, Kenya

https://doi.org/10.53819/81018102t3014 


\subsection{Introduction}

Education plays a vital role in the development of human capital and is linked with an individual's wellbeing and opportunities for better living, (Battle \& Lewis 2002). According to human capital theory, investment in education leads to formation of human capital this is an important factor of economic growth. Education and training imparts skills and productive knowledge and transforms human capital. However, Educational performance is affected by various socioeconomic factors. The factors may range from family background, learning environment and government intervention (Mumiukha, Ngugi \& Ndiga, 2015). In the case of this study, socioeconomic factors will be discussed in relation to educational performance (Baranowska-Rataj, Styrc \& da Silva, 2015). The socioeconomic factors are household income, family size and parents' level of education. The relationship between socioeconomic factors and educational performance of children can be explained in a sociological research (Ghaemi \& Yazdanpanah, 2014). UNESCO (2010) noted that the socio-economic status of an individual may not only determine his/her academic success but also pointed to other socioeconomic factors such as poverty, educational background, occupational and income level of parents. Mweti (2013) identified socio-economic factors as parental level of education, parental income, financial and material support by parent, language, parental involvement in child education and peer group in school environment.

In Malaysia, socioeconomic factors significantly affect the academic performance of school going children. Siah, Christina Ong, Tan, Sim and Xian Thoo, (2018) noted that parents level of education and availability of reading materials at home affects pupils' academic achievement. According to Sulaiman, et al. (2020) adequate facilities, adequate teachers, parental support and favourable environment affects students' academic performance in Malaysia. In Pakistan, the effect of socio-demographic profile of the family, significantly affects academic achievement of school going children (Habibullah \& Ashraf, 2013). According to Onzima (2010), there is a correlation between socio- economic status of the parent and pupils educational attainment in Paksitan. Akhtar (2012) noted that mother's education, income and number of siblings has significant effect on academic achievement.

In Nigeria, socioeconomic factors are directly related to pupils' academic achievement. According to Usman, Mukhtar and Auwal (2016), parent involvement, profession, interest in education, learning materials at home, family size, stability, background, social stratification and socio-economic status of parents are major factors determining the academic achievement of students. Ogunsola, Osuolale and Ojo, (2014) further noted that children from illiterate poor homes perform poorer compared to their counterparts from rich literate households. Moreover, Amoo, Adeyinka and Aderibigbe (2018) claimed that students whose parents have higher socioeconomic status and higher levels of education might have an enhanced regard for learning and more positive ability beliefs on education compared to children of parents with lower socioeconomic status and lower levels of education.

https://doi.org/10.53819/81018102t3014 
In Kenya, socioeconomic factors significantly predict the academic performance of school going children. Nyakan and Yambo, (2016) indicated that failure to pay school levies probably results due to low family incomes and large family sizes that often affect pupils' performance. Low income of parent is a major impediment to academic success and development on the part of the students. Student's academic performance can be predicted by a chain of socioeconomic factors resident in parents, family and network (Michubu, 2013). Nevertheless, the socio ecoinomic factors that influence academic performance in public primary schools may vary hence the nned to conduct a study in the context of in Murang'a South Sub County

\subsection{Statement of the Problem}

National examinations play a significant role in education systems. In the 8-4-4 system of education, Kenya Certificate of Primary Education examination is taken at the end of the eighth year of primary education (Njeri, 2014). Learners who perform well are perceived to have received high quality education essential for sustainable socio-economic development and poverty eradication as opposed to those who perform poorly (Mbogo, 2017). The performance in the national examination is used as a criterion for certification and as a base for selecting pupils to join secondary schools and post-primary technical institution.

Despite the Government of the Republic of Kenya commitment to provide high quality primary education, outstanding pupils' academic achievement remains achallenge in the public primary schools in Murang'a South Sub County. The available statistics indicate that the Sub County has not only consistently performed dismally in the national examination but also experienced observable decline in academic performance. The South Sub County's mean standard score (M.S.S), for example, in 2005 was 237.24; 242.47 in 2006; 241.75 in 2007; 240.56 in 2008 and 236.21 in 2009 (Murang'a South Sub County Education Office, 2019). This poses a serious threat to the socio-economic development of the region and the country at large. There was therefore a dire need to establish the school-based factors influencing academic performance of the public primary schools in the region.

\subsection{Theoretical literature}

This research was based on Walberg's (1998) theory of Educational Productivity that postulates that schools are the focal point for the positive influence on a student's academic success. There are many more factors in achieving success outside the realm of curriculum, and instructional strategies and practices. Community support, parental involvement, and the psychological characteristics of pupils also play a critical role in the academic achievement of all pupils. Walberg's theory is useful in determining the different factors that affect academic achievement (Walberg, 2003). Walberg stated that the most important factor of academic success for pupils from low socioeconomic status is the home environment (Sun, Bradley \& Akers, 2012). It is more crucial than other factors affecting academic achievement, such as parental income and education. Schools cannot change the factors of parental education and income but can have a positive effect on the home environment by educating and working with parents.

Walberg's opines that families from a high socio-economic background are more involved in the educational process than those from a low socio-economic background. The theory postulates that the success of a student's academic achievement is strongly dependent upon parental

\section{https://doi.org/10.53819/81018102t3014}


involvement. These individuals need to have parental involvement in their academic journey in order to attain a high level of educational success. Parental involvement in pupils' academic work may result to higher grades and test scores, long-term academic achievement, positive attitudes and behavior, more successful programs, and more effective schools.

From Walberg's (1998) theory, it is evident that there is strong linkage between pupils' academic achievement and their socio-economic background. This theory is relevant to the current study as the researcher uses it to conceptualize that the student's academic achievement may be influenced by the parent's income, education level of parents and family size. Similarly, other factors which have a bearing on pupils' academic achievement.

\subsection{Empirical literature}

Socio-economic factors have been cited as a determinant of students' performance in national examinations. Basil (2017) points out that poor parental care with gross deprivation of social and economic needs of a child usually yield poor academic performance of the child. Parental involvement in pupils' academic work may result to higher grades and test scores, long-term academic achievement, positive attitudes and behavior, more successful programs, and more effective schools. believes that good parenting supported by strong economic background could enhance strong academic performance of the child. According to auhtor, students' achievements is predicted where the child is properly counseled in the choice of his or her courses and vocation that matches ability, interest and capability.

Low income of parent is a major impediment to academic success and development on the part of the students. Student's academic performance can be predicted by a chain of socioeconomic factors resident in parents, family income level (Baliyan, Madhava \& Baliyan, 2015). Household income has a strong effect on academic performance due to the economic resources allowed for more academic components to be implemented. Resources available at home are an important indicator for the relationship between socioeconomic status and academic achievement. Ali, Hossain and Aktar, (2018) noted children from low income families are more likely to be preoccupied with environmental stressors within their neighborhood such as feelings on insecurity about their safety, housing status, and violence within their community to the detriment of their academic achievement.

Family size in this context refers to the total number of children in the child's family in addition to the child himself (Bysenk \& Locksoh, 2011). However, the family type that a child comes from either monogamous or polygamous family usually has impact on the child academic performance (Considine \& Zappalà, 2012). It is important to note that either of the family type (monogamous or polygamous) family dictates the size of the family. Children from larger families are found to do worse than children from smaller families. However, Shen, (2017) noted that children from larger families have lower levels of education. Smaller family size has been linked with higher academic achievement. Students with fewer siblings are likely to receive more parental attention and have more access to resources than children from large families. The additional attention and support leads to better school performance. Kakumbi, Samuel and Mulendema (2016) investigated pupil background characteristics and academic performance in

\section{https://doi.org/10.53819/81018102t3014}


senior secondary schools in Kitwe district with a view of recommending on how to improve pupils' performance. The analysis of the quantitative data revealed that there was a negative relationship between pupils' age and family size.

Yambo, et al (2016) explored the family based socio-economic factors that affect students' academic performance in public secondary schools in Rongo Sub County, Migori County, Kenya. The study used descriptive survey and correlational research designs. The targeted population was 45 head teachers, 547 TSC secondary school teachers, 14,523 secondary students, 5 ZQASOs. The study found out that Parental level of education significantly affects academic performance 4.6(92\%). The study concluded that parents and guardians should be more enthusiastic about their children's academic performance. The researcher therefore recommended that home environment should be made conducive for learning to supplement what the school provides.

Keter (2016) studied the influence of parents' educational level on pupils' academic performance county, Kenya. The study adopted a survey design targeting population 1821 pupils and 528 teachers from 74 public primary schools. Simple random sampling technique was used to select 22 public primary schools, 158 teachers and 273 class 8 parents. The instruments used for collection included 2 sets of a questionnaire, one for teachers and another for parents. The study found out that educational level of a parent did not significantly influence the academic performance of pupils.

Parents' level of education has been said to have a multifarious impact on children's ability to learn in school. According to Mante, Awereh, and Kumea, (2015) in one study children whose parents had primary school education or less were found to have more than three times low test scores of grade repetitions than children whose parents had at least some secondary schooling. Mante, et al. (2015) points out that parent with little formal education may also be less familiar with the language used in school and this limits their ability to support learning and participate in school related activities.

Family size is documented as a determinant of educational outcomes. Baranowska-Rataj, et al. (2015) asserts that a parent with a small family find it easy to provide for the physical needs of the child and is in a position to give him/her attention, encouragement, stimulation and support with his/her school work. Baranowska-Rataj, et al. (2015) observed that this could have a motivating effect on a child from the small family in comparison with a child from a large family where the parents are always busy trying to find ways of meeting basic needs of the family.

\subsection{Research Methodology}

The study adopted a descriptive survey design utilizing both quantitative and qualitative approaches. The rationale for adopting survey design was that it allows collection of data from a sample of participants from a target population in order to determine the current status of that population with respect to one or more variables (Gay, 1996 \& Orodho, 2009). The locale of the study was Murang'a South Sub County where the researcher had been a teacher. There are 46 public primary schools in Murang'a South Sub County. The target population in the study was all the 46 public primary schools in Murang'a South Sub County, their deputy head teachers, teachers, and pupils. The study involved a sample of 21 deputy head teachers, 105 teachers and

\section{https://doi.org/10.53819/81018102t3014}


210 pupils making a total of 336 participants. Data were collected using a pupils' questionnaire, focus group discussions for the deputy head teachers and teachers, and an observation checklist. Quantitative data were analyzed using descriptive statistics using Statistical Package for Social Sciences (SPSS) version 17. Qualitative data were analyzed using content analysis technique..

\subsection{Results and Discussion}

\subsection{Socio-Economic Factors Influencing Academic Performance}

In this sub-section, socio-economic factors which have bearing on student academic achievement are discussed. These include parental/guardian education, income and pre-occupation with work.

\subsubsection{Parental/Guardian Education}

Parental education is important in relation to homework. Through the questionnaire, the study found that completion of homework/assignments was wanting as indicated by 64 (30.48\%) who complete always, 118 (56.19\%) complete sometimes and 28 (13.33\%) who never complete. This was confirmed by focus group discussions when some participants echoed that there are many cases of pupils who do not complete. In establishing the circumstances under which they do not, the study found that some learners $(33.33 \%)$ fail to complete due to lack of assistance and encouragement at home indicating that the parents/guardians level of education was questionable. This implied that learners lack role models who are inspiration behind attainment of high scores in national examinations leading to prestigious courses. This finding was confirmed by a focus group discussion in one of the schools when a participant lamented over parents' level of education by saying, "Some of the parents are standard 8 leavers while others are school drop-outs who have nothing or very little to offer." This led to the conclusion that majority of the parents/ guardians are ignorant and/or have low regard to education. The researcher hence concurred with Baliyan, et al. (2015) that educated parents take an informed interest in their children's work. The failure to complete homework denoted lack of enough practice on the task and discouraged the teachers from giving and reviewing assignments regularly during class time which translated to poor results.

\subsubsection{Parental/Guardian Income}

Parents'/guardians' income has an important bearing on this study. This is because it is one of the determinants of learner's lifestyle. To establish the implication of the parents'/guardians' income on education, the researcher, through the questionnaire asked the participants to indicate the circumstances under which they fail to complete their homework. The results were indicated in Table 1. 
Stratford Peer Reviewed Journals and Book Publishing Journal of Education

Volume 4||Issue 6 ||Page 16-27||October ||2021|

Email: info@stratfordjournals.org ISSN: 2616-8383

\begin{tabular}{lc} 
Table 1: Circumstances in Which Pupils Fail to Complete Homework \\
\hline Circumstances & $\%$ \\
\hline Living in poorly lit rooms Lack of & 59.29 \\
study area at home Lack of & 33.57 \\
assistance at home & 54.29 \\
Lack of text books to refer & 79.29
\end{tabular}

The study found that most of the parents were low wage earners as suggested by the findings in the Table 1 . The $83(59.29 \%)$ participants who were living in poorly lit rooms implied that their parents/ guardians had not been able to install electricity and solar panels in their homes and could not afford to buy sufficient paraffin making studying impossible. The $47(33.57 \%)$ participants who indicated lack of study area at home implied that there was overcrowding in their homes leaving little or no space at all for studying and lack of important facilities such as tables and chairs which were all essential for the learning process. The study also established that there was an acute shortage of text books despite the Government's effort through the FPE to provide learning/teaching resources. The 111 (79.29\%) implied that due to the low economic status, parents/guardians could not afford to buy essential supplementary books which pupils were not issued with at school, take their children early to school which is a common practice of the wealthier and better educated parents as found Keter (2016), engage their children in extra coaching after school, acquire television sets where they could watch program which aid in promotion of language development among other aspects and to buy internet enabled mobile phones and computers which could all help in accessing more information for education purposes. This translated to lack of enough practice and low vocabulary level essential for education process. The end result was poor academic performance. These parents lack time to help their children in doing homework and inspiring them to achieve high educational goals. The study fully concurs with Basil (2017) that gross deprivation of social and economic needs of a child usually yield poor academic performance of the child.

https://doi.org/10.53819/81018102t3014 
Stratford Peer Reviewed Journals and Book Publishing Journal of Education

Volume 4||Issue 6 ||Page 16-27||October||2021|

Email: info@stratfordjournals.org ISSN: 2616-8383

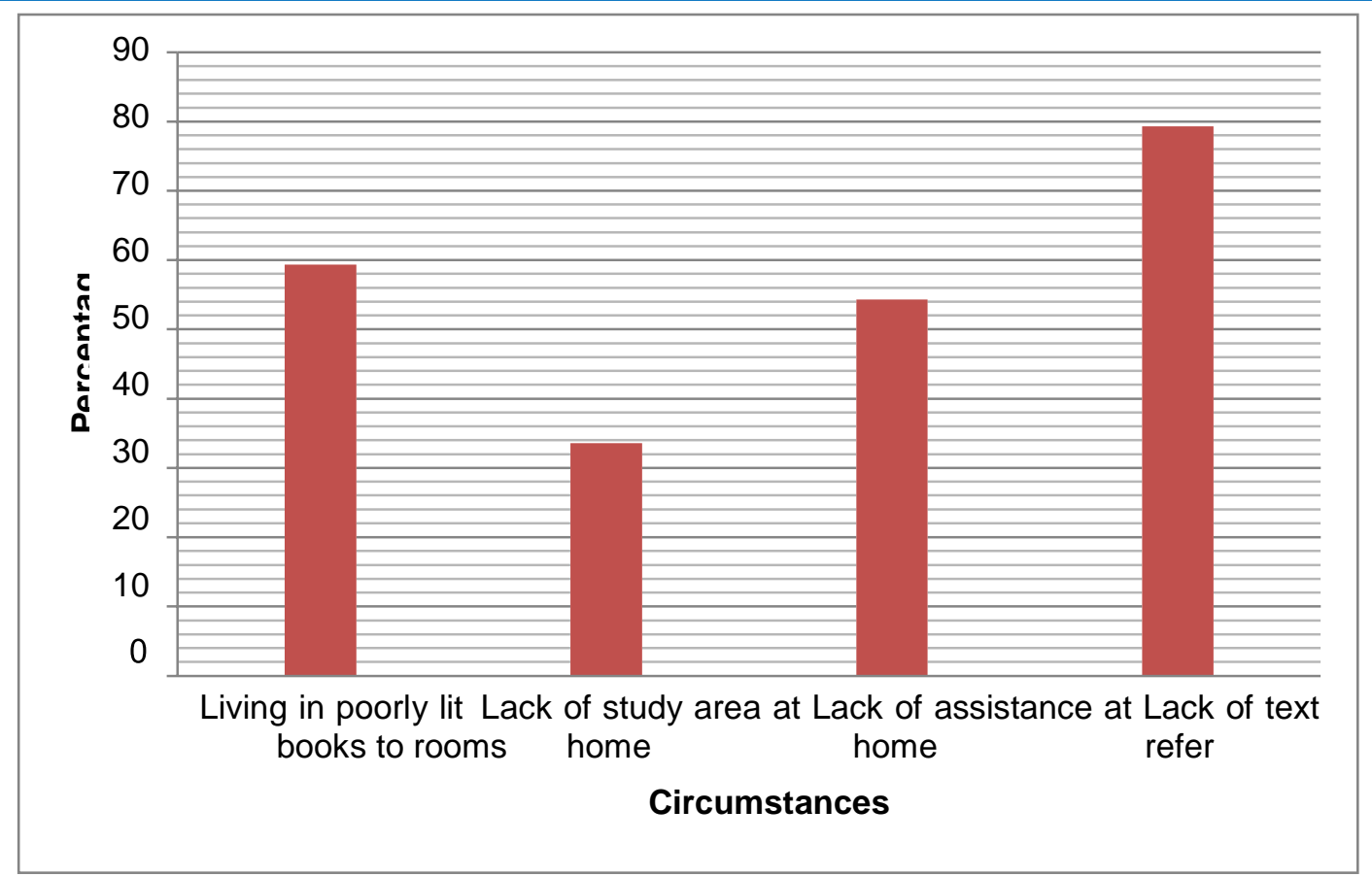

Figure 1: Circumstances under Which Learners Fail to Complete Homework

\subsubsection{Pre-Occupation with Work}

Parent's or guardian's pre-occupation with work was an important variable of this study. This was because it was a determinant of their lifestyle. Their pre-occupation with work revealed their regard to education and its impact on the attendance at school meetings/functions. The attention given to attendance at school functions by parents is indicated in Table 2 as established by the questionnaire.

Table 2: Parents/Guardians Attendance at School Meetings ( $\mathbf{N = 2 1 0 )}$

\begin{tabular}{llll}
\hline Attendance rates & Boys $(\%)$ & Girls $(\%)$ & Av. of both sex $(\%)$ \\
\hline Attend always & 40.00 & 30.48 & 35.24 \\
Attend sometimes & 53.33 & 63.81 & 58.57 \\
Never attend & 6.67 & 5.71 & 6.19
\end{tabular}

The study found that few parents have major regard to education as evidenced by those who attend sometimes (58.57\%) and those who never attend (6.19\%) in comparison with those who attend always. Statistically, it was observed that there was a significant difference between the number of the boy-child parents (91.42\%) and girl-child parents (94.29\%) who avail themselves.

\section{https://doi.org/10.53819/81018102t3014}


Stratford Peer Reviewed Journals and Book Publishing Journal of Education

Volume 4||Issue 6 ||Page 16-27||October||2021|

Email: info@stratfordjournals.org ISSN: 2616-8383

However, there was a notable variation between those who attend always and those who attend sometimes as far as gender was concerned. The attendance incidences were a clear manifestation of low education level of the parents/guardians concurring with Baliyan, et al. (2015) that educated parents tend to attend meetings, exhibitions of work or entertainment at schools when invited. Their in-availability denies them the opportunity to discuss with teachers their offspring progress culminating to low quality education.

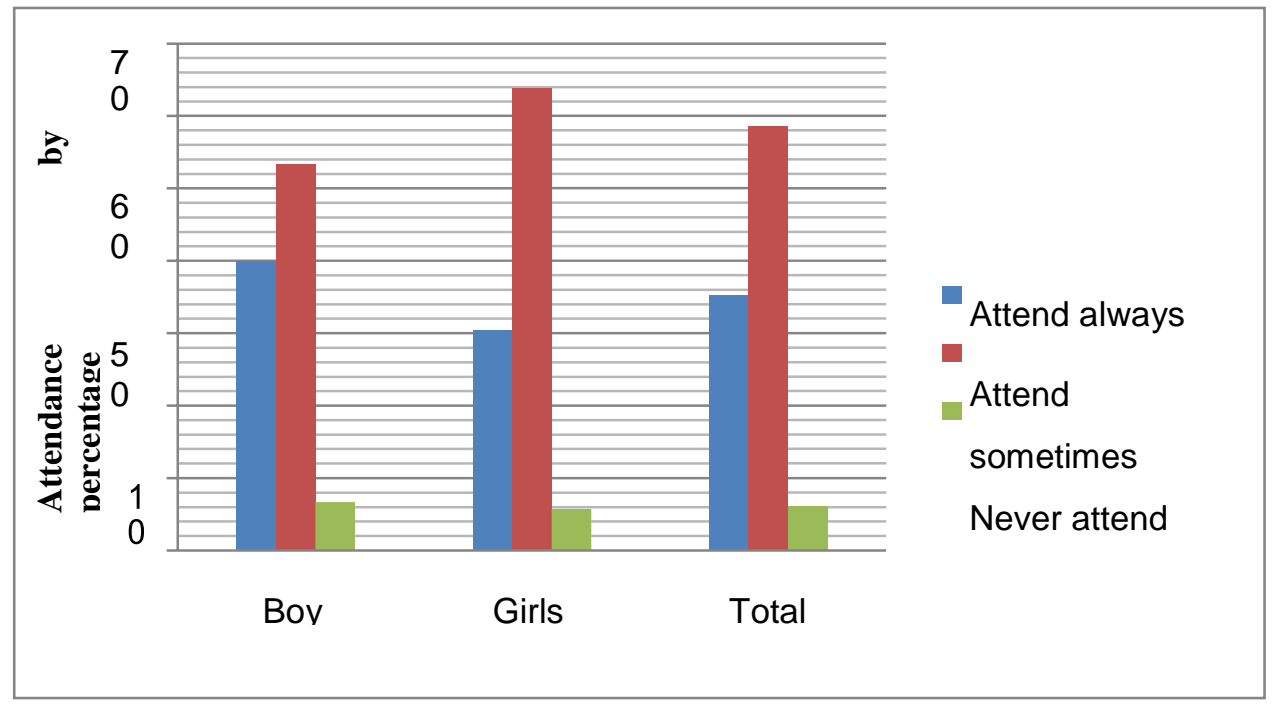

Gender representation

Figure 2: Parents/Guardians Attendance at School Meetings

The study established that majority of the parents/guardians (67.62\%) were unable to attend school meetings due to their pre-occupation with work and lack of interest (34.29\%). It was indeed noted that most of the parents were casual labourers in the neighbourhood coffee plantations, sand and stone harvesters, and peasant farmers. Attendance at school functions was considered to be a waste of valuable opportunities as low income earners (menial workers) and a threat to source of livelihood. This implied that parents and guardians do not realize when things are going wrong, for example, discipline which has a positive correlation with academic performance as argued by Ehiane, (2014). Their poor attendance jeopardizes the learning/teaching process. This led to a conclusion that source of living and its attachment is a determinant of students' academic achievement concurring with Baliyan, et al. (2015).

The study established during the FGDs that some parents work at night and hence could not attend school functions. "Some go to work at night and require time to rest during the day hence consider attendance as secondary," a participant explained. This was perceived as a major threat to discipline as some learners spend the night in the absence of their parents or under the care of their house helps leaving gaps or deficits which could be easily filled by many negative influences. Another FGD revealed that some learners are usually under the care of their grandparents who do not attach a lot of importance to schooling and education, "Some parents work and live far away from their homes leaving their children under the care of their

https://doi.org/10.53819/81018102t3014 
grandparents some of whom cannot make any contribution." The FGDs revealed that some of those who avail themselves were often extrinsically motivated. It was noted that attendance in some schools was due to fear of being penalized. Some schools were reported to have put stiff penalties to push them to attend. Other schools had stringent measures (like keeping children at home) which propel parents/guardians to school. A teacher explained that they ensure pupils remain in their homes and accompany their parents/guardians to school. However, this measure was found to be counterproductive as it leads to loss of valuable instructional time adversely affecting academic performance.

The study established that when parents/ guardians were unable to avail themselves at school when required, they employ some measures which have adverse effect on education outcomes. These included sending their elder sons or daughters to represent them some of whom are primary eight graduates while others are school drop-outs who do not make meaningful contributions to the discussions. This denoted lack of support to the system demoralizing the teaching staff and ultimately results to poor academic performance. Grandparents who were themselves illiterate were reported to feature in school functions representing the parents. It was hence logically argued that majority of the parents/guardians are uneducated. They shun meetings at schools and hence lack the opportunity to discuss their children learning progress with their teachers.

\subsection{Conclusions}

The socio-economic factors included low parental/guardian education level and regard for education; low income of the parents/guardians; and pre-occupation with work. Little regard for education by the community and low education levels attained by the parents/guardians deter most pupils from completing their homework. They lack assistance and encouragement at home.

A large number of pupils could not carry out private studies at home. This was attributed to low income of the community: some parents and guardians reportedly work as casual labourers in the neighbourhood coffee plantations whereby they receive subsistence wage, while others are involved in quarrying the land for stones, sand harvesting and in peasant farming. Due to poor economic status (low earnings) some families live in overcrowded and/or poorly lit rooms. Moreover, they could not afford to buy essential furniture, essential textbooks that were not issued at school, engage their children in extra coaching after school, buy internet enabled mobile phones and computers from which important information for education purposes can be assessed.

Majority of the parents were found to be preoccupied with work. Their preoccupation denied them time to attend to school meetings/functions and observe behavior changes in their children. Absence of parents from homes was noted whereby some children were reportedly left on their own while others under the care of grandparents and house helps who are not keen on discipline and private studies.

\subsection{Recommendations}

There is need for collaboration between the Government of the Republic of Kenya and development partners to work out, introduce and implement sustainable economic activities so as to alleviate poverty in the region.

\section{https://doi.org/10.53819/81018102t3014}




\section{REFERENCES}

Akhtar, Z. (2012). Socio-economic status factors effecting the students' achievement: a predictive study. International Journal of Social Sciences and Education, 2(1), 281-287.

Ali, M., Hossain, M. E., \& Aktar, J. (2018). The impact of socioeconomic status on selecting post-secondary institutions: The case of private universities in Bangladesh. European Journal of Education Studies, 5(8), 185-206.

Amoo, T. B., Adeyinka, O. P., \& Aderibigbe, A. D. (2018). Perceived Effects of Parental Socioeconomic Status on Students' Academic Performance among Teachers in Odeda Local Government, Ogun State, Nigeria. International Journal of Academic Research in Business and Social Sciences, 8(2), 262-272.

Baliyan, S.P., Madhava, K. S. \& Baliyan, P. S. (2015). Influence Of Parental Education And Income Level On Students' Performance In Senior Secondary School Mathematics In Botswana, Global Research Journal On Mathematics And Science Education, 4 (7), 145158.

Baranowska-Rataj, A., Styrc, M., \& da Silva, G. C. (2015). The Impact of Family Size on Educational Attainment in Cross-Country Comparative Perspective. (Umeå University, Sweden).

Basil, A.O. (2017). Socio-Economic Factors Influencing Students Academic Performance in Nigeria-In Ido local Government Area of Oyo. Free Online Library.

Bysenk, K., \& Locksoh, M. (2011). Family characteristics and students' academic performance in English language. Journal of education, 6(2), 114-122.

Considine, G., \& Zappalà, G. (2012). Factors influencing the educational performance of students from disadvantaged backgrounds. In Competing visions: Refereed proceedings of the national social policy conference (Vol. 2001, pp. 91-107).

Ehiane, O. S. (2014). Discipline and academic performance (A study of selected secondary schools in Lagos, Nigeria). International journal of academic research in progressive education and development, 3(1), 181-194.

Gay, L.R. (1996).Educational Research: Competencies for Analysis and Application $\left(5^{\text {th }}\right.$ ed). Englewood Cliffs, New Jersey: Prentice Hall Inc.

Ghaemi, F., \& Yazdanpanah, M. (2014). The relationship between socio-economic status and academic achievement in the efl classroom among Iranian university students. European Journal of English Language and Literature Studies, 2(1), 49-57.

Habibullah, S., \& Ashraf, J. (2013). Factors affecting academic performance of primary school children. Pakistan Journal of Medical Research, 52(2), 47-52.

Kakumbi, Z., Samuel, E. B., \& Mulendema, P. J. (2016). Pupil Home Background Characteristics and Academic Performance in Senior Secondary Schools: A Case Study

https://doi.org/10.53819/81018102t3014 
Stratford Peer Reviewed Journals and Book Publishing

Journal of Education

Volume 4||Issue 6 ||Page 16-27||October||2021|

Email: info@stratfordjournals.org ISSN: 2616-8383

of Selected Secondary Schools in Kitwe District, Zambia. Journal of Education and Practice, 7(22), 19-25.

Keter C. C., (2016). 'Influence of parents' educational level on pupils' academic performance county, Kenya" International Journal of Current Research, 8(9), 39116-39121.

Mante, F. A., Awereh, E. O., \& Kumea, A. O. (2015). Effects of parental involvement on academic performance of pupils: A Case Study at Adukrom Methodist Primary School. Basic Research Journal of Education Research Review, 4(1), 1-7.

Michubu, M. J. (2013). Socio-economic Factors Influencing Students' Academic Performance in Public Secondary Schools in Igembe South District, Kenya. Unpublished Masteres thesis of Department of Educational Administration and planning, University of Nairobi pp, 18.

Mohamad, M. M., Sulaiman, N. L., Sern, L. C., \& Salleh, K. M. (2015). Measuring the validity and reliability of research instruments. Procedia-Social and Behavioral Sciences, 204, 164-171.

Nyakan, P., \& Yambo, J. (2016). Family Based Socio-Economic Factors That Affect Students'academic Performance in Public Secondary Schools in Rongo Sub-County, Migori County, Kenya. Journal of Business Management Science, 2(3), 99-121.

Onzima, R. (2010). Parents Socio-Economic Status and Pupils Educational Attainment: Case study of St. Jude Primary School in Malaba Town Council-Uganda. Retrieved September, 22, 2021.

Orodho, J. A. (2009). Elements of Education and Social Science Research Methods (2 ${ }^{\text {nd }}$ ed.). Maseno: Kanezja Publisher.

Shen, Y. (2017). The Effect of Family Size on Children's Education: Evidence from the Fertility Control Policy in China. Frontiers of Economics in China, 12(1), 37-65.

Siah, P. C., Christina Ong, S. B., Tan, S. M., Sim, C. P., \& Xian Thoo, R. Y. (2018). Factors affecting school choice: What do Malaysian Chinese parents want?. Journal of School Choice, 12(1), 34-51.

Sun, L., Bradley, K. D., \& Akers, K. (2012). A multilevel modelling approach to investigating factors impacting science achievement for secondary school students: PISA Hong Kong sample. International Journal of Science Education, 34(14), 2107-2125.

Usman, M. T., Mukhtar, U. \& Auwal, S. (2016). Parents Socio-Economic Status and Students Academic Performance in Nigeria Educational System, International Journal of Education and Information Technology, 2 (3)14-18.

Walberg, H. J. (2003). Improving Educational Productivity.

Yambo, John M. O. \& Adhanja, Rose \& Nyakan, Peter. (2016). Family Based Socio-Economic Factors that Affect Students' Academic Performance in Public Secondary Schools in Rongo Sub County, Migori County, Kenya. International Journal of Research \& Development Organization (IJRDO) ISSN: 2455-6661. 2. 99-122.

https://doi.org/10.53819/81018102t3014 